\title{
Desorption Isotherms of the Koumiss and Shubat Clots Enriched by Various Additives
}

\author{
Azret Shingisov ${ }^{1}$, Ravshanbek Alibekov ${ }^{1}$, Saparkul Erkebaeva ${ }^{1}, Z_{\text {Zeinep Nurseitova }}{ }^{1}$, Gulbagi Orymbetova ${ }^{1}$, \\ Gulzhan Kantureeva ${ }^{1} \&$ Elvira Mailybaeva ${ }^{1}$ \\ ${ }^{1}$ M. Auezov South Kazakhstan State University, Kazakhstan \\ Correspondence: Ravshanbek Alibekov, M. Auezov South Kazakhstan State University, 160012, Tauke Khan \\ avenue 5, Shymkent city, Kazakhstan. E-mail: ralibekov@hotmail.com
}

Received: December 8, 2014

Accepted: January 14, $2015 \quad$ Online Published: July 31, 2015

doi:10.5539/mas.v9n8p409

URL: http://dx.doi.org/10.5539/mas.v9n8p409

\begin{abstract}
The fermented mare's milk - Koumiss and camel's milk - Shubat are traditional national dairy products in Kazakh cuisine. Concentrated dairy products in the form of clots have a quantity content of useful chemical compounds. In the presented study it was investigated the desorption isotherms of the koumiss and shubat clots enriched by vegetative additives. It was established, that the interface between weakly and strongly bound moisture can be: for the koumiss clots enriched by juices: of a carrot $a_{w}=0,56, u_{x}=0.69 \mathrm{~kg} / \mathrm{kg}$; of a pumpkin $a_{w}=0,58, u_{x}=0,80 \mathrm{~kg} / \mathrm{kg}$; of a beet $a_{w}=0,59, u_{x}=0,81 \mathrm{~kg} / \mathrm{kg}$; as well as for shubat clot, enriched by juices: of a carrot $\mathrm{a}_{\mathrm{w}}=0,62, \mathrm{u}_{\mathrm{x}}=0,73 \mathrm{~kg} / \mathrm{kg}$; of a pumpkin $\mathrm{a}_{\mathrm{w}}=0,65, \mathrm{u}_{\mathrm{x}}=0,67 \mathrm{~kg} / \mathrm{kg}$ and of a beet $\mathrm{a}_{\mathrm{w}}=0,63, \mathrm{u}_{\mathrm{x}}=0.66 \mathrm{~kg} / \mathrm{kg}$.
\end{abstract}

Keywords: dried dairy products, fermented, camel's milk, mare's milk, koumiss, shubat

\section{Introduction}

\subsection{Koumiss and Shubat}

One of the advanced directions in the development of healthy foodstuff with therapeutic actions is fermented dairy products on the bases of mare's milk - koumiss and camel's milk - shubat, enriched by vegetable origin bioactive substances with vitamins and microelements (Faye and Konuspayeva, 2012). According to the variability of milk composition, nutritional and medicinal properties (true or postulated) could be potentially an important added value for producers and dairy sector (Konuspayeva et al, 2009).

The chemical compositions of mare's and camel's milks are specified for geographical origin. Personal data from Kazakhstan showed significantly higher fat matter and total protein contents, but lower lactose content compared to other references from Central Asia (Malacarne et al, 2002). As well as protein content in mare's milk is higher than in human milk and lower than in cow's milk; casein concentration in mare's milk is intermediate between the other two milks. Fat content is lower in mare's milk compared to human and cow's milk. Distribution of di- and tri-glycerides in mare's and women' milk is similar (Saitmuratova et al, 2001).

In addition microelements play important role in the formation of milk structural proteins and affect the quality and food value of dairy products. Microelements (especially $\mathrm{Cu}, \mathrm{Fe}, \mathrm{Zn}$ and $\mathrm{Ni}$ ) can act as catalysts of certain chemical reactions. Deficiencies of them are causes of the various pathological changes in the human organism (Alibekov et al, 2014).

\subsection{Vacuum-Sublimation Drying Method}

Milk is extremely perishable, yet for a number reasons it is desirable to preserve it for later consumption. Today, drying is most important method for preservation of foodstuff (Varnam \& Sutherland, 1994). For the maximum product saving of original quality, the most promising preservation method is the vacuum-sublimation drying. However, this method requires large energy expenditures. Therefore, a research of new ways for reducing the energy costs of this drying method is one of important tasks in the Food industry (Shingisov, 2011).

Heat and mass transfer processes occurring during drying of food products in the frozen state in a vacuum are complex nature because the process of evaporation of moisture from the product surface is necessary to connect with the structure and phenomena occurring inside it. From the viewpoint of the thermodynamics of the drying process some features of products in a frozen state in a vacuum can be divided into the following groups: 
- The first group of features of heat and moisture transfer can be attributed the phenomenon of interaction of the mobile phase with a dry skeleton of the product itself. Status of the mobile phase in the product is determined by the energy and moisture forms of communication that must be considered for the selecting the drying method and its calculation;

- The second group of features of heat and moisture transfer phenomena includes energy and mass of the movable phase within the product. These phenomena depend on the structure of the product. As it is known, a large part of the open pores are interconnected, and therefore the amount of moisture in the pores determines the ratio between the amount of evaporated and diffused from the deep layers of the product water;

- The third group of features of heat and moisture transfer includes physical phenomena arising from the transfer of moisture from the surface of the product to its environment (air). The intensity of the mass and energy transfer in this case is determined by the state of the boundary layer.

Study of the state of the boundary layer during the drying a lot of scientific papers are devoted (Kamovnikov et al, 1985). However, still there is no sufficiently clear view not only of the physical transport mechanism, but also on the qualitative impact of moisture transfer on heat transfer (Bykov, 1987). The mechanism of transfer of moisture, kinetics of transport and energy costs in the process of freeze-drying depend not only on moisture content, but also the structure of the product and forms moisture binding dry carcass material (Flaubenbaum et al, 1986).

Analysis of a several papers (Izbasarov, 1999) devoted for the studying of patterns of changes in the kinetic curves shows that the various forms of drying rate curves indicate the different nature of the relationship with the product moisture. However, it is not possible to determine the nature of the product a significant impact on the intensity of the internal moisture transfer and the rate of evaporation of moisture, as well as to establish the total effect of the moisture content; the physicochemical properties of drying and drying curves describe by theoretical predictions (Kauhcheshvili, 1985). In this regard, presently semi-empirical laws and model for different product classes are useful. For intensify of the freeze-drying process requires strict control of all relevant factors (Key, 1983). Currently, industrial freeze-dryers are often operated solely on the basis of experience of staff (Riedel, 1961). This means that except the temperature and pressure of the residual air in the sublimator, operators do not use any other parameters. In such a situation freeze-dryers are served with deliberately exaggerated amounts of energy consumption (Ginzburg and Savina, 1982).

Control of the drying process is a challenging task, and in some cases impossible. Thus, control of the drying process by controlling the residual pressure of the air in the sublimator can not always be achieved. The reason is the variations in the residual pressure in sublimator not always adequate response for the changing in the water state of the product due to a number of reasons. These reasons can include variations in the product structure in the process of drying that leads for a changing in the thermodynamic parameters, such as the chemical potential $(\mu)$, water activity (AW), the binding energy of moisture (L) (Kutsakova \& Bogatyrev, 1987).

Thus, on the basis of the above mentioned analysis it has concluded the following:

- Basic directions of improving of technique and technology of sublimation drying are the study of the interaction of the product with its environment (air) based on the analysis of static and drying kinetics;

- Accumulated scientific and practical potential in thermodynamics of moist air can be used to directly control of the process of sublimation drying.

- For intensify the drying process, in the laboratory of the food production technology of M.Auezov' SKSU has been developed a new device for the freezing, based on the intensification of the drying process by increasing the heat transfer coefficient on the air side.

The created device provides a grid configuration of freeze drying product with a plurality of through holes. As a result, in the product increases the contact area between the product and air, thereby repeatedly increases the coefficient of heat transfer from the surface of the product to its environment (Kamerbayev, 2002).

In order to reduce energy consumption during a drying of liquid foods has developed a new technology of water condensation contained in the compositions of koumiss and shubat enriched by herbal supplements from other components before drying with preserving the original quality. In this technology, for the separating of water as a serum from compositions of koumiss and shubat, there were used protein coagulated ingredients (rennet, pepsin, calcium chloride) and apple vinegar, as components reducing the activity of the aqueous medium. In the separation of clot and serum the serum yield for koumiss enriched by plant origin juices was $69-72 \%$ and $60-63 \%$ for shubat of the total product weight (Shingisov, 2008). 
According to the currently existing theory drying regularities of heat - and mass transfer processes during the vacuum freeze-dried foods are described by curves of drying rate that is defined as the slope of the tangent drawn through the point of the experimental curve drying rate, corresponding to a certain moisture content of the material (Varnam and Sutherland, 1994). However, this method does not fully describes the regularities of heat and mass transfer processes in their vacuum-sublimation drying, especially at the end of the process, when the drying curve asymptotically approaches the line of equilibrium moisture (Shervud et al, 1982).

It is known that the character of the heat - mass transfer processes during the vacuum-sublimation drying depends on the thermodynamic state of the water contained in the drying product and characterized by a water activity (Ginzburg, 1973). In this regard, for the disclosure of the character of the heat - and mass transfer processes were studied the water activity in koumiss and shubat enriched by vegetative additives in the vacuum vacuum-sublimation drying (Shingisov, 2011).

\section{Methods.}

\subsection{Used Raw and Equipment}

As research raw materials were used a fresh diurnal koumiss of the farm "SAP" and shubat of the farm "Gulmairam" those is situated in the "South Kazakhstan Oblast" (SKO). In the capacity of additives for the enriching koumiss and shubat were taken a carrot, a pumpkin and a beet from local producers of the SKO. Juices from plant material were obtained by the household (Braun) brand juicer. For enrichment of koumiss and shubat by vegetable juices and their thickening and separation of the clot from the serum it was used the technology developed by the laboratories of the Kazakhstan Research Institute of Processing and Food industries. As per this technology at the separation of the clot and serum the output for a koumiss enriched by plant origin vegetable juices was $69-72 \%$ and for a shubat - $60-63 \%$ of the total product weight.

For the determining of water content in the samples of the koumiss and shubat clots enriched by vegetative juices it was used the method of convective drying in the sublimation chamber at the $102 \div 105^{\circ} \mathrm{C}$. Water content of the koumiss clots enriched by juices: of a carrot $\mathrm{W}_{\mathrm{i}}=88,3 \pm 0,02 \%$, of a pumpkin $\mathrm{W}_{\mathrm{i}}=87,8 \pm 0,02 \%$ and a beet $\mathrm{W}_{\mathrm{i}}=89,2 \pm 0,02 \%$; of the shubat clots, enriched by juice: of a carrot $\mathrm{W}_{\mathrm{i}}=86,8 \pm 0,02 \%$, of a pumpkin $\mathrm{W}_{\mathrm{i}}=87,8 \pm 0,02 \%$ and a beet $\mathrm{W}_{\mathrm{i}}=88,2 \pm 0,02 \%$.

The experimental laboratory vacuum sublimation apparatus consists of: sublimation camera of circular section with diameter $0.5 \mathrm{~m}$ and a length $0.7 \mathrm{~m}$ for the product drying; the vacuum pump AVPR-60D of the "Hydromeh" company (Russia) to create a residual pressure at the sublimation chamber within $5 \cdot 10^{-4} \mathrm{kPa}$; and low-temperature refrigeration unit (Russia) for the ensuring a drying temperature in the sublimation chamber and traping of water steam existed from the sublimation chamber. In the sublimation chamber air temperature varied from minus $5{ }^{\circ} \mathrm{C}$ until minus $15^{\circ} \mathrm{C}$ by a thermo-regulating valve of the SPORLAN company (Russia).

At the beginning of the experiment, the researched samples were enriched by vegetative additives koumiss and shubat clots, as well as a distilled water were frozen at the $-18^{\circ} \mathrm{C} \div-20^{\circ} \mathrm{C}$ in the refrigerator of the INDESIT company during 8-10 hours in a specially designed cylindrical form with a strict observance of the same thickness (thickness $\delta=0.006 \mathrm{~m}$, diameter $\mathrm{d}=0,135 \mathrm{~m}$ and mass $\mathrm{m}=0,01 \mathrm{~kg}$ ). Then by assistance of the "Testa625 " device (Germany) with an umbrella for determining water activity, the water activity of the samples was determined. Furthermore the product samples and a distilled water ice were placed in freeze chamber in a chessboard pattern. During the drying process the installation was periodically breaking (an interval per 1 hour.), finally the product was removed, and after that a mass and a water activity were measured.

The temperature measuring at the freeze chamber was provided by a temperature sensor ZET 7020 Termo TC 485 with an accuracy of $1,5 \pm 0,01 / \mathrm{t} /$ (Russia), and the mass measurement - with weights VLKT - 500 with an accuracy of $\pm 1 \%$ weighting (Russia). Drying the clot samples were done until a final humidity at the $268 \mathrm{~K}$, $263 \mathrm{~K}$ and $258 \mathrm{~K}$.

\subsection{Method of the Mathematical Treatment of Experimental Results}

The product moisture changing was calculated at the current time by the formula:

$$
\mathrm{W}_{\mathrm{p}}=\left(\mathrm{G}_{\mathrm{j}}-\left(\mathrm{G}_{\mathrm{j}}-\mathrm{G}_{\mathrm{p}}\right)\right) / \mathrm{G}_{\mathrm{j}}
$$

where, $\mathrm{W}_{\mathrm{p}}$ - a product moisture at the measuring time, $\%$;

$$
\begin{aligned}
& \mathrm{G}_{\mathrm{i}} \text { - an initial weight of the sample, } \mathrm{g} \text {; } \\
& \mathrm{G}_{\mathrm{p}} \text { - a sample weight at the measuring time, g. }
\end{aligned}
$$

The experiments were performed three times for the each drying temperature. In order to avoid gross experiment 
errors, the experimental data were processed by mathematical statistics. For this purpose the uniformity of the dispersion estimates was determined by using the Kohren criterion based on the following formula:

$$
G=\frac{\left[S^{2}\left(y_{u k}\right)\right]_{\max }}{\sum_{u}^{n} S\left(y_{u k}\right)}
$$

where $\left[\mathrm{S}^{2}\left(\mathrm{y}_{\mathrm{uk}}\right)_{\max }-\right.$ maximal dispersion of each exit;

$$
\sum_{u}^{n} S\left(y_{u \kappa}\right) \quad \text { - sum of dispersion of all exits. }
$$

The hypothesis of dispersion uniformity is accepted, if the estimated value of the Kohren criterion $\mathrm{G}_{\mathrm{p}}$ is less than the table value $\mathrm{G}_{\mathrm{t}}$, i.e.

$$
\mathrm{G}_{\mathrm{p}}<\mathrm{G}_{\mathrm{T}}
$$

Checking of the hypothesis about the significance of the coefficient " $\mathrm{b}$ " was conducted according to the estimated dispersion:

$$
\begin{array}{r}
\varepsilon\left(b_{i}\right)=t(p, f) \cdot S\left(b_{i}\right) \\
S^{2}\left(b_{i}\right)=\frac{S^{2}\left(\overline{y_{i}}\right)}{N}=\frac{\sum_{u}^{N} \sum_{K}^{M}\left(y_{u \kappa}-y_{u}\right)}{N \cdot(m-1) n \cdot N}
\end{array}
$$

where, $\mathrm{t}(\mathrm{p}, f)$ - table value of the Student criterion for a given probability $(\zeta=0,95)$ and quantity of freedom degrees $f_{j} ; S^{2}\left(\bar{y}_{i}\right)$ - average value for the entire experiment reproducibility dispersion of average exit value in each row; $\mathrm{N}$ - dispersion number.

Coefficient " $\mathrm{b}_{\mathrm{i}}$ " is considered significant if

$$
\left|b_{i}\right|_{>} \mathcal{E}\left(b_{i}\right)
$$

$$
f_{\mathrm{t}_{\mathrm{kp}} \text { is determined for freedom quantity }} f
$$

$$
f=N(m-1)
$$

where, $\mathrm{N}$ - experiments quantity

$\mathrm{m}$ - number of cycles (in our case $\mathrm{m}=3$ )

equation approximations are provided by using the "Excel-2007" software

\section{Results and Discussions}

\subsection{Analysis of the Drying Processes}

Analysis of drying kinetics curves (Figures 1,2, and 3) shows that the samples of koumiss and shubat clots as other foodstuff consist in three periods: the establishment of the operational parameters, constant drying and falling drying rates.

The period of the setting operational parameters has been begun with the volume vacuumization and the residual pressure reduction till the $50 \div 60 \mathrm{~Pa}$. This period was during 8-12 minutes.

The period duration of the continuous drying of the fermented milk product's clot was $5,20 \div 6,0$ hours.

The spread of the drying failing speed time for koumiss clots enriched by vegetative additives, were $3,0 \div 3,40$ hours, and for shubat clots enriched by the same additives, were $2,0 \div 2,30$ hours. 




(a)

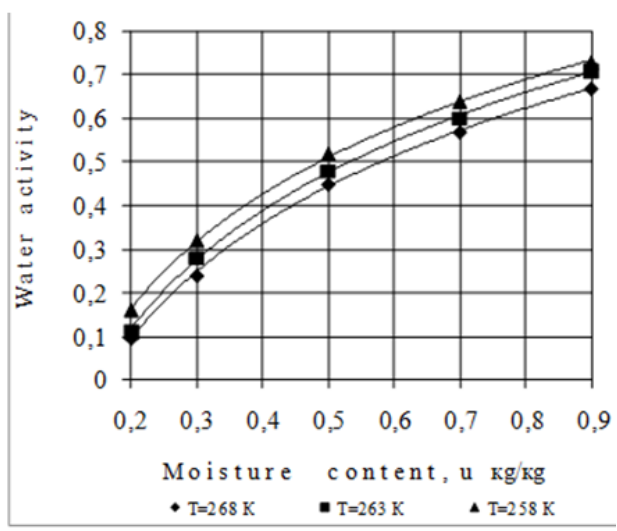

(b)

Figure 1. Desorption isotherms of the koumiss (a) and shubat (b) clots enriched by carrot

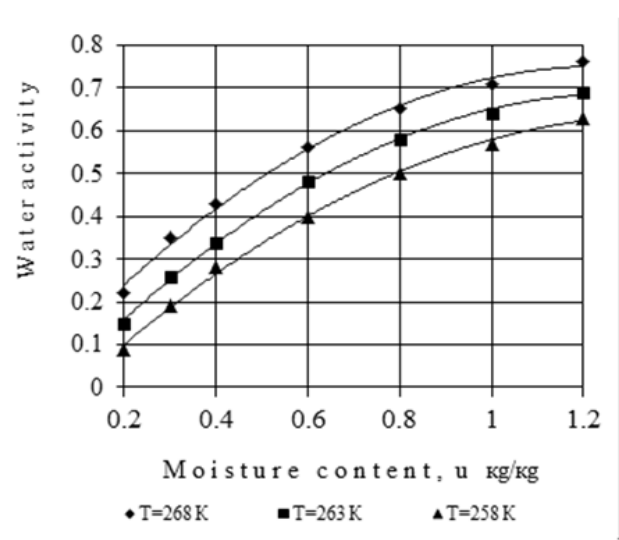

(a)

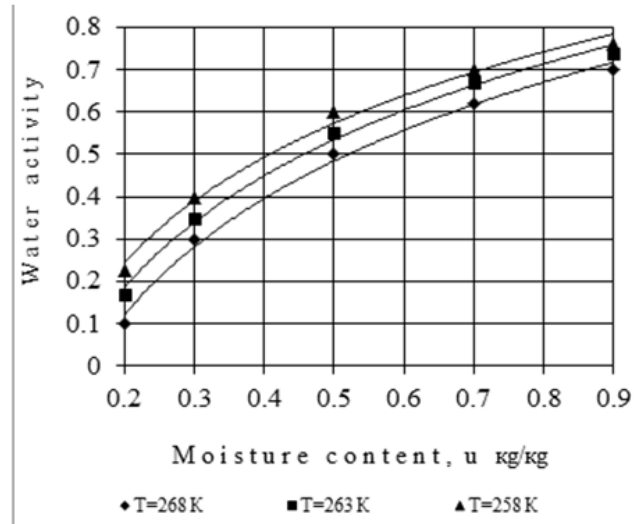

(b)

Figure 2. Desorption isotherms of the koumiss (a) and shubat (b) clots enriched by pumpkin



(a)



(b)

Figure 3. Desorption isotherms of the koumiss (a) and shubat (b) clots enriched by beet

From the shown plots (Figures 1, 2 and 3) can be seen there are four zones with boundaries at three points on the curves of the desorption isotherms.

I zone is an area till the first point of inflection characterized by formation of stable hydrate complexes with high bond energy and moisture strict orientation of the molecule relative to the water and the dry carcass material and practically does not depend on temperature. The zone is located in the range for shubat clot enriched by carrot juice $0<\mathrm{u}_{\mathrm{x}}<0,072 \mathrm{~kg} / \mathrm{kg}$; pumpkin juice $0<\mathrm{u}_{\mathrm{x}}<0,074 \mathrm{~kg} / \mathrm{kg}$; beet juice $0<\mathrm{u}_{\mathrm{x}}<0,081 \mathrm{~kg} / \mathrm{kg}$. 
II zone is region of multilayer adsorption of moisture that in contrast to the first zone is characterized by the mobility of water molecules and flexible molecular chains of the protein complex and take the most favorable conformations. This zone corresponds to the interval for clot shubat enriched by juice: carrot $0,072<\mathrm{u}_{\mathrm{x}}<0,36$ $\mathrm{mg} / \mathrm{kg}$; pumpkin $0,074<\mathrm{u}_{\mathrm{x}}<0,32 \mathrm{~kg} / \mathrm{kg}$; beet $0,081<\mathrm{u}_{\mathrm{x}}<0,34 \mathrm{~kg} / \mathrm{kg}$.

III zone is characterized by the diffusion of water molecules in the intermolecular space corresponds to a protein complex and moisture of mezo and macro capillars (for shubat clots enriched by juice: carrot $0,36<\mathrm{u}_{\mathrm{x}}<0,70$ $\mathrm{kg} / \mathrm{kg}$; pumpkin $0,32<\mathrm{u}_{\mathrm{x}}<0,82 \mathrm{~kg} / \mathrm{kg}$; beets $0,34<\mathrm{u}_{\mathrm{x}}<0,91 \mathrm{~kg} / \mathrm{kg}$ ). The binding energy of the moisture with a dry carcass material is significantly reduced, the internal energy increases, hence, the mobility of water molecules, significantly increases the probability of microbial growth.

IV zone is after the third singular point. The moisture in this zone has a small binding energy of water (close to pure water) due to the attenuation, the flexibility of the molecular chains of the protein complex and further significantly increases moisture sorption leads to separation of the protein products of these chains and essentially to their diffusion in the solvent.

In terms of selecting the optimum storage of the dried product is great interest in the second zone. Based on the results of the experiment can be determined that the maximum value of the moisture content for storage conditions can take a value equal to $\mathrm{u}_{\mathrm{x}}=0,32-0,36 \mathrm{~kg} / \mathrm{kg}$ of dry matter, which corresponds to a water activity equal to $\mathrm{a}_{\mathrm{w}}=0,321 \div 0,325$.

Based on these studies we can conclude that the process of removing moisture in freeze dried product in the following sequence.

In the first stage removes loosely bound water from the ice crystals on the surface of the product. In the second phase due to the temperature difference between the surface of the front drying and all the frozen sample some of the weakly bound water is removed from the low value of the energy due to the frame. The rest (in the lower layers) continues to sublimate from the inner layers to the front surface drying. After this period, when almost all the frozen moisture and a certain amount of tightly bound water is removed and the sample temperature rises to about $0{ }^{\circ} \mathrm{C}$, the value of residual moisture reaches $15-17 \%$ of dry weight. In the third period, when the temperature reached $36^{\circ} \mathrm{C}$ drying, the water fraction is removed, the associated connections and strong frame product, whereby its residual moisture is reduced to $4,0 \div 4,5 \%$.

Analysis of the Figures 1, 2 and 3 shows that the moisture desorption isotherms of the enriched by vegetative additives koumiss and shubat clots, have a complicated form and by the character of desorption isotherms' curves the koumiss clots differ from the shubat clots. This distinction is explained by the different structure of the product and the nature of the moisture diffusion process in the investigated products[14].

The type of desorption isotherms' curve has an evidence, that the clots of koumiss and shubat enriched by vegetative additives relate to the colloid-porous materials.

Whereas the conventional dividing a moisture of the product into weakly and strongly bonded, we may assume that the interface can be: for a koumiss clots enriched by juice: of a carrot $a_{w}=0,56$ unit portion, $u_{x}=0.69$ $\mathrm{kg} / \mathrm{kg}$; of a pumpkin $\mathrm{a}_{\mathrm{w}}=0,58$ unit portion, $\mathrm{u}_{\mathrm{x}}=0,80 \mathrm{~kg} / \mathrm{kg}$; of a beet $\mathrm{a}_{\mathrm{w}}=0,59$ unit portion, $\mathrm{u}_{\mathrm{x}}=0,81 \mathrm{~kg} / \mathrm{kg}$; for a shubat clot, enriched by juice: of a carrot $a_{w}=0,62$ unit portion, $u_{x}=0,73 \mathrm{~kg} / \mathrm{kg}$; of a pumpkin $\mathrm{a}_{\mathrm{w}}=0,65$ unit portion, $\mathrm{u}_{\mathrm{x}}=0,67 \mathrm{~kg} / \mathrm{kg}$ and of a beet aw $=0,63$ unit portion, $\mathrm{u}_{\mathrm{x}}=0.66 \mathrm{~kg} / \mathrm{kg}$.

\subsection{Mathematical description of drying desorption isotherms.}

The experimental data treatment of the water activity value dependence upon the koumiss and shubat moistures enriched by vegetative additives can be satisfactorily described by the logarithmic form:

$$
\mathrm{Y}=\mathrm{A} \cdot \ln x+\mathrm{C}
$$

where: $\mathrm{A}$ and $\mathrm{C}$ - constant coefficients from the product type dependent.

$\mathrm{A}$ and $\mathrm{C}$ coefficients are indicated at the table 1 .

Table 1. A and C coefficients values for koumiss and shubat clots enriched by vegetative additives.

\begin{tabular}{cccccc}
\hline № & Product & Temperature, & \multicolumn{2}{c}{ Coefficients values } & Approximation authenticity \\
\cline { 3 - 5 } & & K & A & C & \\
\multirow{2}{*}{1} & carrot & koumiss clots enriched by vegetative additives & \\
& 268 & 0,3227 & 0,7183 & 0,9892 \\
& 263 & 0,3372 & 0,6877 & 0,9967 \\
\hline
\end{tabular}




\begin{tabular}{|c|c|c|c|c|c|}
\hline \multirow{3}{*}{2} & & 258 & 0,3266 & 0,6342 & 0,9981 \\
\hline & pumpkin & 268 & 0,302 & 0,710 & 0,9915 \\
\hline & & 263 & 0,309 & 0,637 & 0,9971 \\
\hline & & 258 & 0,305 & 0,566 & 0,9965 \\
\hline \multirow[t]{4}{*}{3} & beet & 268 & 0,307 & 0,710 & 0,9947 \\
\hline & & 263 & 0,308 & 0,638 & 0,9884 \\
\hline & & 258 & 0,311 & 0,577 & 0,9986 \\
\hline & \multicolumn{5}{|c|}{ shubat clots enriched by vegetative additives } \\
\hline \multirow[t]{3}{*}{1} & carrot & 268 & 0,366 & 0,774 & 0,9893 \\
\hline & & 263 & 0,383 & 0,748 & 0,9967 \\
\hline & & 258 & 0,367 & 0,708 & 0,9851 \\
\hline \multirow[t]{3}{*}{2} & pumpkin & 268 & 0,350 & 0,810 & 0,9845 \\
\hline & & 263 & 0,372 & 0,787 & 0,9976 \\
\hline & & 258 & 0,383 & 0,742 & 0,9978 \\
\hline \multirow[t]{3}{*}{3} & beet & 268 & 0,347 & 0,771 & 0,9962 \\
\hline & & 263 & 0,368 & 0,700 & 0,9897 \\
\hline & & 258 & 0,377 & 0,662 & 0,9934 \\
\hline
\end{tabular}

\section{Conclusion}

Thus in the result of the investigations was determined the koumiss and shubat clots enriched by carrot, pumpkin and beet juices can be relevant to the colloid-porous materials.

Following the conventional division of moisture in the product into weakly and strongly bonded, we may assume that the interface can be: for koumiss clots enriched by juice: of carrots $a_{w}=0,56$ unit portion, $u_{x}=0.69 \mathrm{~kg} / \mathrm{kg}$; of pumpkin $\mathrm{a}_{\mathrm{w}}=0,58$ unit portion, $\mathrm{u}_{\mathrm{x}}=0,80 \mathrm{~kg} / \mathrm{kg}$; of beet $\mathrm{a}_{\mathrm{w}}=0,59$ unit portion, $\mathrm{u}_{\mathrm{x}}=0,81 \mathrm{~kg} / \mathrm{kg}$; for shubat clot, enriched by juice: of carrots $\mathrm{a}_{\mathrm{w}}=0,62$ unit portion, $\mathrm{u}_{\mathrm{x}}=0,73 \mathrm{~kg} / \mathrm{kg}$; of pumpkin $\mathrm{a}_{\mathrm{w}}=0,65$ unit portion, $\mathrm{u}_{\mathrm{x}}=$ $0,67 \mathrm{~kg} / \mathrm{kg}$ and of beet aw $=0,63$ unit portion, $u_{\mathrm{x}}=0.66 \mathrm{~kg} / \mathrm{kg}$.

For the practical application is important the optimum storage condition of the water content in the dried product. On the base of the experimental results, we can predicate that the maximum moisture content for storage conditions can take a value equal to $\mathrm{u}_{\mathrm{p}}=0,32-0,36 \mathrm{~kg} / \mathrm{kg}$, which corresponds with a value of a water activity equal to $\mathrm{a}_{\mathrm{w}}=0,321 \div 0,325$ unit portion.

Symbols and abbreviations

$\mathrm{W}_{\mathrm{i}}$ - water content in the product before drying,\%;

$\delta$ - thickness of the product, $\mathrm{m}$;

$\mathrm{d}$ - diameter of the product, $\mathrm{m}$;

$\mathrm{m}$ - product mass, kg;

$\mathrm{a}_{\mathrm{w}}$ - water activity, unit portion;

u - product specific moisture, $\%$;

$\mathrm{W}_{\mathrm{d}}$ - moisture content by dried substance, $\%$;

\section{Indexes of designation}

i - initial;

$f$ - finished;

$p$ - product;

\section{References}

Alibekov, R. S., A. A. Utebaeva, K. A. Urazbayeva, Usenova, S. O., \& Ermolaeva, E. A. (2014). Sensory evaluation in the standardization of tomato juice with various functional additives. Herald of Kazan Technological University, 17(7), 208-212, Kazan, Russia.

Bykov, B. A. (1987). Kinetics of the aggregation of soil particles in the pseudo clotting and driving layer, Diss. Cand. of Tech. Sciences, p. 235, Sverdlovsk, Russia.

Faye, B., \& Konuspayeva, G. (2012). The sustainability challenge to the dairy sector - The growing importance of non-cattle milk production worldwide. International Dairy Journal, 24(2), 50-56. 
http://dx.doi.org/10.1016/j.idairyj.2011.12.011

Flaubenbaum, B. L., Tanchev, S. S., \& Grinshin, M. A. (1986). Bases of the canning of the food products. Agroporomizdat, p. 494, Moscow, Russia.

Ginzburg, A. S. (1973). Theory and techniques bases of food products drying. Eds. Food Industry, p. 528, Moscow, Russia.

Ginzburg, A. S., \& Savina, I. M. (1982). Mass transfer characteristics of food products, p. 280. Light and Food industry, Moscow, Russia.

Izbasarov, D. S. (1999). Drying of food vegetable materials, p. 312. Almaty, Kazakhstan.

Kamerbayev, A. U. (2002). Thermodynamic bases of hydratation and drying of polycomponented food systems. Doctor of Tech. Sc. abstract of a thesis, specialty: 05.18.12. (p. 25). Almaty, Kazakhstan.

Kamovnikov, B. P., Malkov, L. S., \& Voskoboinikov, V. A. (1985). Vacuum and sublimate drying of food products. Eds. Agropromizdat, p. 285. Moscow, Russia.

Kauhcheshvili, E. I. (1985). Physico-technical bases of the food products processing. Agropromizdat, p. 256, Moscow, Russia

Key, R. B. (1983). Introduction to the industrial drying technology. English transl. Science and technics, p, 262, Minsk, Belarus.

Konuspayeva, G., Faye, B., \& Loiseau, G. (2009). The composition of camel milk: A meta-analysis of the literature data. Journal of Food Composition and Analysis, 22(2), 95-101. http://dx.doi.org/10.1016/j.jfca.2008.09.008

Krisher, O. (1961). Scientific bases of the drying technics, Foreign literature, p. 540, Moscow, Russia.

Kutsakova, B. E., \& Bogatyrev, A. I. (1987). Intensification of heat and mass transfer during food products drying, Agropromizdat, p. 412, Moscow, Russia.

Malacarne, M., Martuzzi, F., Summer, A., \& Mariani, P. (2002). Protein and fat composition of mare's milk: some nutritional remarks with reference to human and cow's milk. International Dairy Journal, 12(11), 869-877.

Riedel, L. (1961). Zum Problem des gebundenen Wassers in Flelsch. Kältetechnik, p. 300.

Saitmuratova, O. Kh., Sulaimanova, G. I., \& Sadykov, A. A. (2001). Camel's milk and Shubat from the Aral Region Chemistry of Natural Compounds; (Volume 37, Issue 6, pp. 566-568).

Shervud, T. (1936). Drying of the solids, Gosletizdat, p.250, Moscow, Russia.

Shervud, T., Pigford, R., \& Uilki, Ch. (1982). Mass transfer. English transl., Chemistry, p. 695, Moscow, Russia.

Shingisov, A. U. (2011). The optimization of vacuum-sublimation drying parameters of cultured milk foods by using microwave energy. Journal of Food Industry, pp. 22-24. Moscow, Russia.

Shingisov, A. U. (2008). Definition of thermodynamic exponents of condensed domestic fermented milk products, enriched by vegetative additives, at drying. Journal of Dairy Industry, 5, 85-86. Moscow, Russia.

Varnam, A. H., \& Sutherland, J. P. (1994). Milk and Milk Products: Technology, Chemistry and Microbiology. Eds. Routledge, Chapman \& Hall, Incorporated, p. 451.

\section{Copyrights}

Copyright for this article is retained by the author(s), with first publication rights granted to the journal.

This is an open-access article distributed under the terms and conditions of the Creative Commons Attribution license (http://creativecommons.org/licenses/by/3.0/). 